\title{
CHINA, GEOPOLITICS AND GEOECONOMICS. HOW NOT TO FALL INTO THE TRAP OF NARRATION?
}

\author{
Grzegorz MALINOWSKI \\ (Received: 17 October 2018; revision received: 25 June 2019; \\ accepted: 8 July 2019)
}

\begin{abstract}
Chinese infrastructural projects like the "Belt \& Road Initiative" or the "Chinese $16+1$ Initiative" are trapped in geopolitical narratives. Geopolitical concepts dressed in scientific robes make the logic of warfare begin to prevail over the logic of cooperation. As a consequence, something that was to be an opportunity for less developed countries, becomes the axis of conflict between the great powers. In this paper, I identify the logic of warfare as an underlining characteristic of geopolitical reasoning and show why it is incompatible with economic approach. I also argue that geopolitical concepts are not scientific theories, but rather self-fulfilling prophecies. This theoretical background allows to detect the biggest obstacles related to many Chinese initiatives, and also indicates some necessary means to neutralize geopolitical narratives.
\end{abstract}

Keywords: China, geopolitics, geoeconomics, logic of war, self-fulfilling prophecies, Belt \& Road, $16+1$ initiative

JEL classification indices: B41, F42, F51, F52, P48

Grzegorz Malinowski, Assistant Professor at Kozminski University, Department of Economics, Warsaw, Poland. E-mail: grzesiekmalinowski@gmail.com 


\section{THE LOGIC OF WARFARE}

The classification of interpersonal relationships has been developed under praxeology (Kotarbiński 1955). They can take the form of positive collaboration, i.e, cooperation, or negative collaboration, i.e., a fight. The actual functioning of societies, however, is never limited to the dominance of one type of relationship, but rather constitutes a combination of cooperation and fight in various fields and in varying proportions.

Behind every form of interpersonal relationships there are thinking entities. Therefore, if we refer the reasoning behind the act of cooperation as the logic of cooperation and the reasoning related to fight as the logic of war, it may appear appropriate to claim that the teaching of economics is performed in a bit of isolation from the second type. Although economists are familiar with the ideas of fight and conflict (Schelling 1960), they usually use them to define the conflict of interest, which is a phenomenon of competition for particular resources. However, solving problematic situations of this kind is usually executed with the use of first type logic and without analogy to argumentations within the logic of warfare (or war). It seems that the majority of conflicts described in economic research may still be classified as examples of "rivalry", despite the accompanying terminology filled with quasi-military expressions.

Therefore, deeper analysis of issues related to the logic of war and comparing it to the logic of cooperation seems essential. Deliberations of this kind should preferably be preceded by reference taken from metaphorical language, which may not be suitable for excessive use for scientific purposes, though it allows understanding of a particular problem intuitively.

As Luttwak (2001) indicates, a thought experiment can be conducted. If Smith asks a randomly chosen pedestrian how to go from town $\mathrm{A}$ to town $\mathrm{B}$, then this randomly chosen person will certainly (assuming their good will and lack of any prejudices) point out the best, safest, most comfortable and possibly the cheapest way. Such common sense answers show that the interlocutor conforms to the principles of the logic of cooperation.

What would, however, the pedestrian's advice be like, if Smith asked them the way from town $\mathrm{A}$ to town $\mathrm{B}$ in a different manner, under the assumption that a deadly enemy waits for him in town B wanting to hunt him down? Most probably, the necessity of taking the enemy's presence into account will radically change the interlocutor's way of thinking. Since Smith's opponent expects his visit, then this hostile person will certainly secure the most obvious route and try to catch their enemy on it. Therefore, the logic of war will suggest choosing the less obvious and much more "uneconomic" way. Following this thought, Smith will surely 
receive additional recommendations regarding the choice of season, time of the day and favourable conditions in which his trek should be taken, and all these suggestions will certainly be closer to the most burdensome and extreme conditions, radically different than those from the previous example. All that would be done with the aim of surprising the opponent. This is exactly how reasoning reaches a paradox. The "good way" is wrong precisely because it is good, whereas the "wrong way" becomes a good one for its being wrong. The paradoxicality of this situation shows that there is a leap from reasoning within common-sense categories to reasoning in the categories of war.

However, reasoning applied within the logic of war is not at all irrational, because the conclusion logically follows presumptions. In the example considered, the aim of reasoning was to specify a "good" way from town A to B. Nevertheless, the definition of a "good way" varies, depending on whether it is used within the logic of cooperation or the logic of war. In the first case, a "good way" may be defined as the way that leads people to their destination in the shortest possible time and at minimum expense. On the other hand, the second case indicates that the concept of a "good way" means basically "the way that is not expected by the opponent".

The presence of an enemy and a situation that may be compared to the zerosum game, in which one player's gain is equal to another one's loss, is crucial to the logic of war. This is exactly why war, which is understood in its primary sense as taking military actions, illustrates the practical application of the logic of war best. An example of a chess game or poker game also constitutes a relatively good metaphor, especially with regard to the process of planning moves, which is mostly based on trying to predict the opponent's reaction to a particular situation rather than analysing one's own position.

The presence of an active, responsive opponent makes the logic of war characterized by a peculiar paradox. The marks of said paradoxicality might be found even in cultural wisdom, as illustrated by the famous Latin paroemia (or proverb in English) "Si vis pacem, para bellum" ("If you want peace, prepare for war"). The paradoxicality of the logic of war lies exactly in contradictions of this kind. The "wrong way" turns out as "good", an army's victorious march becomes its defeat (due to the fact of leaving the supply), and the most powerful weapon becomes the biggest weakness since it makes the opponent to take preventive measures.

Sulek (2001) also drew attention to one feature of the logic of war that is directly reflected in economic sciences. Based on the analysis of 36 most important battles of the $19^{\text {th }}$ and $20^{\text {th }}$ centuries, which indicated that the stronger party suffered more minor losses than the weaker party, he came to the conclusion that the 
microeconomic law of diminishing marginal returns in an event of war becomes its contradiction, that is a principle - the higher the expense, the better the effect ${ }^{1}$. These results are converting the economic principle of effect maximization at a given level of expenses into the principle of effect maximization and expense minimization.

\section{LOGIC OF WAR AND GEOPOLITICS}

The aim of this paper is not to deepen the genetic or cultural sources of the logic of war. However, it is difficult not to venture the claim that its presence is closely related to the fact of human's territoriality. People are territorial animals, i.e. they define and defend their territory. People are also herd animals, therefore, since their very beginning, they tend to create societies. Countries, as human communities, reflect these primary instincts.

Despite globalization and multidimensional structural changes of the contemporary world, manifesting in, among others, the increased significance of international organizations and companies, the most important decisions regarding the model of economic growth, law systems or military actions are still taken at the level of nation states. For this reason, it is worth putting forth a question of whether the actions taken by states are preceded by reasoning typical of the logic of cooperation or rather of the logic of war?

Had the logic of cooperation been dominant in the actions taken by states, the expected observations would be as follows (Luttwak 1990):

1. States concentrate on achieving optimum and global economic objectives;

2. States treat technological innovation as an objective in itself;

3. States promote and popularize free trade as a means of multiplying the wealth of nations;

4. Managing natural resources (especially, natural gas and crude oil) is conducted, as any other business activity, in accordance with economic balance indications;

5. The investment policy of companies (both private and state) is conducted in accordance with economic balance indications.

Meanwhile, in reality, observations of a different kind can be made:

1. States are concentrating on maximizing the output of their own economies;

1 Also, in an economy, within the so-called "endogenous growth theory", the assumption about diminishing marginal returns is being loosened. 
2. States try to maximize profits from technological innovations;

3. States impose duties, trade barriers, quotas, trading delays or so-called "rules" of origin in order to maximize their own benefits from trade;

4. Managing natural resources frequently takes the form of confrontation;

5. The investment policy of companies is often dependent upon the international situation.

It seems then that the above observations allow for drawing a safe conclusion that states, for systemic reasons, tend to behave in a way that is not always oriented on maximizing economic rationality. In other words, states demonstrate attitudes that are more easily explainable within the logic of war than within the logic of cooperation. Nonetheless, the absolute dominance of the logic of this type cannot be claimed. More typical of the action taken by states is rather the mutual intermingling between these two types of rationality. This constitutes a natural consequence of the political situation a given state is in. It can be expected that under the conditions of increased political insecurity caused by actual or potential conflict, thinking in categories of fight will start to achieve dominance. On the other hand, times of peace will be more favourable for international cooperation. However, none of the rationality types can be completely eliminated. Economic rationality is irremovable, because it is closely related to the rareness of goods - the element that cannot be ignored, even within military actions. Whereas the rationality of war is permanent due to the territoriality characteristic of humans, the nation state structure subordinated to its requirements.

These two types of rationality can be found in the foreign policy of states, starting from very ancient times. Also, it seems possible to link them with the famous Rodrik's trilemma (2011), which states that globalization, sovereignty and democracy are in some ways mutually exclusive. We cannot have hyperglobalization, with its movement of goods, people and finances along with national sovereignty, in which states are able to choose their own policies, along with democracy - we have to give up at least one of those. According to Rodrik, three combinations of these entities are available. These are: (1) National sovereignty and Democracy, (2) Hyper-globalization and National sovereignty and (3) Hyper-globalization and Democracy. Each variant is related with a certain trade-off. The inability to achieve all three goals together seems to be fully understandable from the perspective of logic of war. For sooner or later, national sovereignty manifests itself in the form of uneconomic, often considered irrational decisions, which, however, are fully justified from the perspective of the paradox logic of war.

In this very context, geopolitics appears, and it is usually treated as a reflection on the meaning of geographical conditions to phenomena and a process observed 
in the political life of countries. Nevertheless, in practice, geopolitics tends to be (wrongly) identified with so-called "geographical determinism", an idea of considering geographical factors as the most important to country development.

\section{GEOPOLITICS, SCIENTIFIC DISCIPLINE AND SELF-FULFILLING PROPHECIES}

Discussions about the meaning and position of geopolitics in the processes of economic development do not cease. Mainstream economists practically ignore the significance of the geographical factor in the process of economic development, reducing it to climate, the presence of natural resources and the size of agricultural land. However, the representatives of more heterodox schools of economic thoughts have a different opinion. They underline the relevance of natural geographical barriers, access to maritime trade or simply the topography.

Both sides of this conflict have their reasons. The first is guided by the scientific necessity of idealization: that is, of reducing the complexity of phenomena to a few basic factors, whereas the others underline the deficits and potential mistakes of thinking reduced to such extent.

However, in this article I am going to propose quite a different perception of geopolitics, which expands onto its two definitions. The author of the first one is Mackinder (1904). He claimed that geopolitics has to be understood as "the impact of geography on politics: a reflection on how distances, topographies and climate influence the actions of states and people." On the other hand, Andrzej Piskozub (2010) describes geopolitics simply as "manipulating geography for political reasons."

The above-mentioned definitions constitute two contrary ways of looking at geopolitics. As long as the former requires treating it as a scientific and research project, oriented on discoveries and gradually reaching the truth typical of academicians, the latter implies the substantial emptiness of geopolitics and its complete subordination to current political goals.

The supporters of Mackinder's definition will treat geopolitics as a scientific discipline, which will consist of a thorough analysis of argumentation, verification of empirical data and consideration of contradictory hypotheses. On the contrary, the supporters of Piskozub's definition will seek to find geopolitics in the justification for the rationality of this or another concept of developing international relations.

However, there is something that connects these two contradictory views. That thing is narration. Whether we have to deal with a geopolitician, he conveys some 
narratives that I understand here, literally, as stories with a plot, hidden sense and (usually) some kind of morale.

I would like to suggest then that the ideas presented by geopoliticians should be treated as narratives. The particular feature of them is the inability to assign them the logical value of truth or falsehood. This means that none of these geopolitical concepts can be claimed true or false: we can only declare our position - for or against one of them. The choice is, however, determined by axeological reasons rather than the power of argumentation.

The adopted viewpoint is certainly unacceptable for those to whom geopolitics is an academic discipline or science. Nevertheless, taking into consideration the fact that a demarcation line defining boundaries between science and non-science is rigor that enforces the appropriate way of justifying claims, it has to be stated that geopolitical ideas known to the author are lacking this rigor. Moreover, concepts created on the basis of geopolitics are impossible to classify. It is, thus, because shaping them is connected with using the logic of war, which de facto allows for any form of irrationality as long as they can surprise the opponent.

Let me use an example. In July 2018, Donald Trump, the President of the United States, met Vladimir Putin, the President of Russia in Helsinki. Without entering into the details of that meeting and focusing on its geopolitical comments, several geopolitical interpretations can be distinguished. Some people claim that the President of the US showed his "subordination" to the President of Russia. Others say that the President of the US "domesticated" the President of Russia. Still others state that the actions of the US President move toward the gradual diversion of the US from Europe. By contrast, it seems obvious to other observers that President Trump wants to strengthen the American presence in Europe.

It is worth pointing out that the above-mentioned claims have a few attributes - they are mutually contradictory, none of them can be eliminated (because each is based on firm and logical arguments) and each constitutes a part of some kind of broader narration regarding the situation of the US, Europe and the world. It has to be interjected that the mentioned "broader narratives" are also mutually contradictory. To sum up, I would like to underline the fact that there is no rigorous methodology allowing one to accept the superiority of some geopolitical ideas over others.

In the context of methodology, it must be mentioned that in geopolitics, as well as in all scientific disciplines, a particular subject, goal and method of studies can be indicated. The underlying goal of geopolitical endeavour is to explain the behaviour of states and to discover the regularities in this behaviour. On the other hand, subject of the studies basically is the political map of the world. Geopolitics achieves its goals through two particular methods: 
- Analysis of international relations with the assumption that geographical factor is essential to understand the behaviour of states;

- Analysis of political discourse, especially statements of prominent politicians, which enable to spot regularities and understand how these statements shape politics.

Analysis of international relations is crucial and it consists of two fundamental steps. The first one is an analysis of countries from the geographical perspective (geographical location and characteristics of the territory, climate, natural resources, population, political system and economy). The second one is the analysis of interactions between countries which stresses the (1) relations between states (determined by geography) and (2) similarities and differences of states' behaviour, determined by geography.

Up to this point, the methodology of geopolitics may be disputable but more or less fits the social sciences, however, geopolitics does not stop here. It tries to go from the description of the behaviour of states on local scale, to the description of universal regularities that govern the behaviour of states on global scale - so called "big theories". This very transition is a methodological abuse and it can be called an "original sin" of geopolitics. Popular statements proclaimed by geopoliticians, like "eternal laws of geopolitics", "iron laws of geopolitics", "objective laws of geopolitics" only reflect a positive approach to science that has been rejected by philosophy of science a long time ago.

It does not mean though that geopolitical concepts are irrelevant. On the contrary, they are of enormous significance! However, their strength can be found not in the scientific truth that they discover, but rather in the number and quality of supporters they gain. The scientist, under his/her represented discipline, finds new regularities in the surrounding world and then expresses them as a theory or law. What is crucial to this process is the fact that at no time the claims formulated by the scientist can influence the examined reality (Soros 2008). This means that, for instance, the physician determining the temperature of freezing has no impact on this condition, and the biologist estimating the number of genes in a given organism, even if mistaken, cannot change anything in the genotype of the examined species. Examining the body and the scientists' opinions are independent from the examined subject.

However, in social sciences and geopolitics, something different can be observed. It turns out that conclusions drawn from examination may considerably change the functioning of the examined subject. Therefore, developed opinions (theories and concepts) directly influence the examined subject. Let us imagine that the main analyst of the biggest investment bank in the world claims that the shares of a Polish bank A are strongly overvalued. Let us assume that his conclusion is based on "firm", analytical and real evidence. It is easy to predict what 
the next day's stock market session will look like for bank A and how investors will act.

In the second scenario, we can change the assumption and say that the analyst made a mistake. His statement was about bank A, but he really meant bank B. In contrast to bank B, the condition of bank A is very good. It can then be claimed that the fundamental analysis of bank A is very favourable. The problem is that the analyst's mistake will be discovered after a year.

Meanwhile, until the mistake is discovered, bank A's quotations will decrease significantly, and thus, its reputation will suffer. The cost of capital will grow notably, which will influence the forecasted profits. In the meantime, the bank's supervisory board will exchange management, and the market will start to notice substantial staff movements in the bank, which will only magnify the impression that there is "something wrong" with bank A.

What is important in this fictional situation is the fact that the mistaken claim regarding the bank's economic foundation became true because a significant number of investors believed it. This is exactly how the examining body (analyst) and research process (examination) can directly influence the examined subject (bank A).

The example provided fits the concept of self-fulfilling prophecy developed by Merton (1948). The causal connection complied with the following pattern:

(1) X believes that "Y" is " $p$ "

(2) X takes action "b"

(3) Given (2), Y becomes "p".

The characteristic feature of Merton's concept is that this false belief becomes true only because it changed people's behaviour. In other words, a primarily false concept becomes the true one. However, in a broader sense, not only may the false statement become true, but additionally the statement that currently has no assigned logical value.

The causal connection of self-fulfilling prophecies is exactly what I consider as a tool for noticing the role and significance of geopolitical concepts in world politics. Stock market speculators often rely on famous stock market regularities, such as the "Santa Claus rally" (a rise in stock prices during the Christmas season) or "sell in May and go away" (the month of May marks the beginning of summertime, which means the drop in the stock market). The validity of these phrases depends solely on whether the participants of the investment process believe them or not. If yes, then they are true, if not - they turn out to be false. Analogically, in the case of geopolitical concepts (theories), we do not dispose of a proper methodological tool that would allow for verifying their validity. However, it is not a secret that some geopolitical concepts are supported by prominent, influential politicians, and this is exactly why some ideas created on their grounds 
become a self-accelerating process. In other words, if an average person thinks that opinion $\mathrm{X}$ is of no significance to the world, but opinion $\mathrm{X}$ is shared by the advisors of the US president, the presidents of Russia and China, then opinion $\mathrm{X}$ sets "the rules of the game", becoming the interpretational framework of a given situation. A neutral observer may consider opinion $\mathrm{X}$ to be true and fair, since it explains the behaviours of leading geopolitical "players" best. However, the source of this impression is not the scientific adequacy of this opinion, but rather the fact that the observed behaviours were developed under its influence.

This text presents the ambivalent approach to geopolitics. On the one hand, it appears to be an intellectual human activity imitating science. Nevertheless, geopolitics is not a science, but rather an illustration of the need to understand chaotic processes and giving them any sense, so typical of a human narrative. This view is certainly very aggressive and de facto equalizes the study of geopolitics to the study of this or another mythology. After all, myths were also created with the need of understanding the reality.

However, on the other hand, geopolitics requires more thorough, systematic research, and its influence on world politics cannot be underestimated. Developing geopolitical concepts significantly shape the beliefs of both the masses and political elites, thanks to which they influence political decisions. This is exactly why they should be identified, described and, in some cases, also neutralized.

\section{CLASSIC GEOPOLITICAL CONCEPTS}

\subsection{Mackinder}

I use the term "geopolitical concept" to describe a certain collection of logically coherent claims explaining the political history of a given territory (usually, the whole world of its part that in a specific period can be treated as an economictechnological leader) by means of appealing to the broadly understood geographical factors. The provided definition implies that geopolitical concepts might be of a global nature - when they concern the whole world or several continents, but they can also be of a local nature - when they concentrate on the territory of a given country or a geographical region. It is also worth noticing that geopolitical concepts focus mainly on these factors that the development economics is silent about. Although economists investigating the economic growth always take into consideration factors, such as climate, agricultural potential or access to natural resources, they look into these factors from a slightly different perspective. Most importantly, they usually do not pay attention to the strategic and military significance of a given area and, moreover, they perceive a map in a static, not 
dynamic way - as geopoliticians do. For the economist, territory constitutes an established state - the area of political-economic interactions between its inhabitants. The geopolitician, on the other hand, perceives territory as "an element of the game", a part of the greater whole, the subject of rivalry that, thanks to its qualities, may be of strategic significance, i.e. advantageous in a potential military confrontation. Using this analogy, it can be stated that geopolitics resembles more microeconomics than macroeconomics. When the bank management board considers the possibility of taking over a smaller market "player", they have to take into account the benefits and risks connected with such a move as well as the competitors' reactions to it. Meanwhile, the macroeconomist or economic politician considers the banking sector from the regulatory and optimizing perspective, finding out what kind of factors may improve its functioning. In other words, the microeconomist (bank chairman), while trying to predict competitors' reactions, uses a certain form of the previously defined logic of war, that is something that a macroeconomist usually does not take into account.

Although there are many different geopolitical narratives, concepts and doctrines, it is possible to distinguish a few classic, fundamental ones among them that not only provide direction for the subsequent research, but also become the standard of carrying out geopolitical deliberations.

The first concept fundamental to geopolitics is Mackinder's "Heartland doctrine". It was formulated for the first time in 1904 with a telling title "The geographical pivot of history". Mackinder draws the geopolitical model of the world in a very innovative way. Although geography is a stable factor, not susceptible to any modifications, he still manages to present a completely different way of

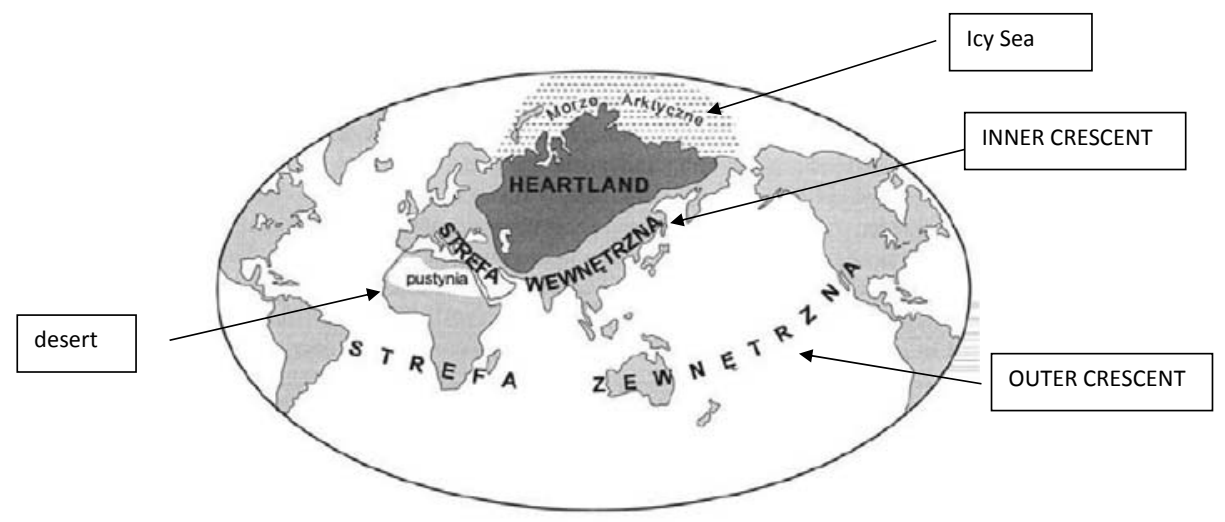

Figure 1. The Heartland concept

Source: Moczulski (1999). 
looking at the map and justify his opinions by means of indicating correlations between political history and geography.

According to Mackinder, the geopolitical map of the world is concentrated mainly on the "World-Island", which comprises the continents of Europe, Asia and Africa. The World-Island includes the essential part of global land, is inhabited by the majority of the human population and, from the historical perspective, plays the most important role, because the most significant political events have taken place in its territory. It specifically means that this region decides the world's fate. The World-Island is not a uniform formation and can be divided into two areas. Its most important part is Heartland that is the so-called "pivot area". This term involves the northeast part of the Eurasian continent. Heartland is expanded between the area around the Pacific Ocean in Siberia in the east and Volga in the west, bordered by the Arctic to the north and Pakistan and Afghanistan to the south. Therefore, Heartland may be, with some degree of approximation, equated with Russia. Heartland is surrounded by a so-called "inner crescent" that can be most conveniently thought of as the interlinked territories of China, India, the Middle East, North Africa as well as Western and Central Europe. The WorldIsland is surrounded by an "external crescent" that comprises the territories of South Africa, Australia, North America and Japan.

The characteristic feature of Heartland is its lack of access to sea routes. That is exactly why this area is (1) poorer than the inner crescent (maritime trade constitutes the cheapest and most economically effective type of transport) and (2) it cannot be taken over by means of maritime military expansion. From the historical point of view, Heartland was dominated by nomadic peoples who owed their military successes to the cavalry. This area is also characterized by a much harsher, colder climate that enforces a specific way of governing.

The model presented by Mackinder allows for a particular historical reflection indicating that history so far can be perceived as the record of continuous struggles of Heartland with the inner crescent. After all, every empire that was created within the area of the inner crescent collapsed under the influence of Eastern peoples' military expansion, involving, for instance, the expansion of the Huns, Mongols or Turks. The predominance of Eastern nomads resulted from the military significance of horseback riding that could not be defeated until the discovery of continuous fire, which somehow ended the predominance of the cavalry over the infantry. The powers dominating in the Heartland always tried to gain access to maritime trade, but they never managed to achieve it for a longer period. Mackinder warns that, in the case of achieving this goal and accessing the maritime routes, expansive land power will obtain global hegemony over all continents.

May the citation of Mackinder's universal geopolitical law be the summary of his doctrine described above: "Who rules Eastern Europe commands the 
Heartland; who rules the Heartland commands the World-Island; who rules the World-Island commands the world" (Eberhardt 2011: 261). The thread of Eastern Europe appearing in it seems a bit surprising. The majority of subsequent studies are related directly to the territory of Poland. Why does this region have such a fundamental meaning? The reason for that is the significance and topography of the Middle European Plain - a wedge-shaped geographical formation that has a length of 1500 kilometres, a width of 150 kilometres to the west and 350 kilometres to the east, which extends between France and the Ural Mountains, the Baltic Sea and the Carpathians. This area has a major military significance, since it is described as a "gateway to Heartland". If we equate Heartland to Russia, we will notice that existential threats to this country have always been passing through this precise gateway. The Poles in 1605, Swedes in 1708, Frenchmen in 1812, Germans in 1914 and Germans in 1941 - the direction of the invasion each time was the same. The Middle European Plain is the gateway to Heartland because it is possible to redeploy through it the armies of many thousands to the east. What is more, its physical shape - a wedge - gives the attacker the advantage. The wedge is gradually expanding to the east of Poland, enabling the attacker to choose freely the attack direction. Moreover, an army moving to the east does not encounter any strategic obstruction until the Ural Mountains. Thanks to such attributes, the territory of Eastern Europe, especially Poland, becomes exactly what the Thermopylae Isthmus was during the war of Sparta and Xerxes - the area that gives a strategic advantage once it is controlled. Precisely because of the above, some geopoliticians call this localization a "crumple zone" - where the powers of Heartland and the inner crescent continuously fight for control.

\subsection{Spykman}

Mackinder's doctrine systematized the way of thinking about territorial relations, though global foreign policy and geopolitical strategy related to it were based on another concept that shares a lot of similarities with Mackinder's view; however, it leads to substantially different conclusions. Namely, it concerns the Rimland doctrine developed by Nicholas Spykman (1944). This American political scientist basically accepted Mackinder's proposal of distinguishing between the Heartland and so-called "inner crescent" which he called "Rimland". Without exploring geographical differences between the territorial scope of Heartland and Rimland in Mackinder's and Spykman's concepts, respectively, it is possible to identify Rimland as an area of Eurasia's periphery situated near the Pacific Ocean, Indian Ocean and Atlantic Ocean. According to Spykman, this area constitutes a broad 


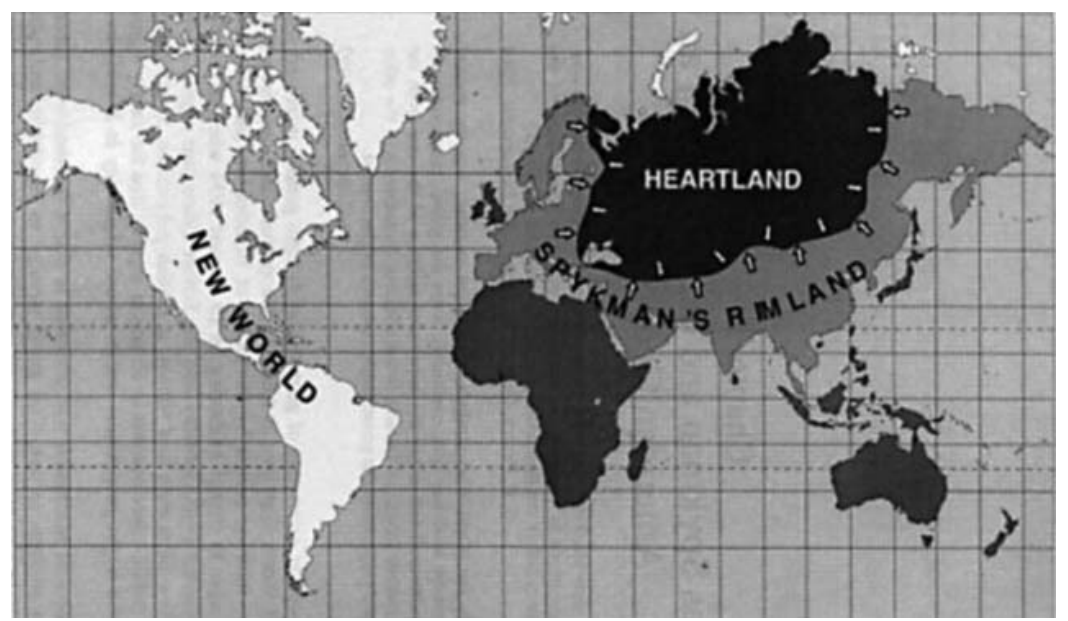

Figure 2. The concept of Rimland

Source: Wikipedia.

buffer zone separating a maritime power from the land-based one. It is pushed by two powers from both sides - from the sea and from the mainland.

In accordance with Spykman's concept, Rimland is precisely the most politically important region of the Eurasian continent. Control over Rimland gives power over Eurasia, and power over Eurasia ensures dominance over the world. However, the territory of Rimland is not uniform. It can be divided into: the eastern part, which is situated in Chukotka and reaches Alaska, the middle part - with India going deep into the Indian Ocean, the Middle East and the western part, whose border is established by the European peninsula.

In Spykman's doctrine, there is no equivalent understanding of a "gateway to Heartland" as the area of strategic significance that, once controlled, ensures the dominance over Rimland. Contrarily - Spykman underlines that Rimland is strongly varied in a political and cultural sense and that no empire managed to fully control this territory. Although such an attempt was made during the World War II, when two countries of Rimland situated in its two extreme parts - Germany and Japan - tried to take this land over, together with an attempt to defeat the power dominating in the Heartland (USSR).

Superiority of Rimland over Heartland stems from, among others, the richness of natural resources. As long as Mackinder could claim that the majority of crucial natural resources are located in Heartland, Spykman, writing his dissertation a few decades later, could not possibly speak in a similar tone. After all, the breakthrough discovery of the automotive industry, that is the diesel engine, is dated back to 1893, whereas the first engines of industrial importance were not 
constructed until 1908. Mackinder published his concept in 1904, which means that it was set in the reality of the first Industrial Revolution, not in the second one as happens in the case of Spykman's doctrine.

Control over the territory of Rimland seems unachievable, but it does not necessarily mean that some form of controlling this part of the world is not possible. This is where an issue regarding the role played by sea routes is raised. Spykman's doctrine says that world domination can be achieved not through taking over the mainland, but rather the oceans and their trade routes. This situation is obviously possible when the dominating power, thanks to the presence of its fleet, is able to control strategic areas whose maritime block would paralyze the entire system of international trade. An example of such a strategically crucial place is the Strait of Malacca or the Suez Canal.

The concept of Rimland has become the basis of the American post-war foreign policy. The US has become a maritime power whose presence is especially visible when another geopolitical opponent tries to contest its maritime domination. However, controlling maritime routes requires financial contributions that get bigger once they concern more distant parts of the world. Similar to Japan that Great Britain was not able to keep its dominance over, contemporary China tries harder and harder to escape the maritime tutelage of the US, which, from China's perspective, means greater autonomy and from the US perspective - disturbing the post-war world order.

Mackinder's and Spykman's doctrines are the two most popular narratives connected with geopolitics. Although they lead to basically different conclusions, both the way of thinking presented in them and applied terminology play an important role in the theory of international relations. What is more, the conditions of rivalry between powers force different geopolitical narratives to be used for predicting the opponent's decisions because it can never be guessed which one is the opponent's inspiration.

\section{GEOPOLITICS AND GEOECONOMICS}

On the basis of the doctrines previously described, determining various predictions regarding the nature of international tensions and places triggering conflicts becomes possible. The geographical-historical method of justifying claims behind geopolitical doctrines, on the one hand, allows for prediction of particular players' behaviours, and on the other hand, it somehow sentences international policy to repeating history and functioning within well-known patterns through the mechanism of self-fulfilling prophecy. 
Although geopolitical deliberations focus mainly on the architecture of world security, which makes them connected tightly with the military aspect of world politics, it has to be noted that the contemporary geopolitical rivalry is more often supported by the use of economic tools. In other words, it is believed (Blackwill Harris 2015) that the big game stipulated in geopolitical doctrines (such as Mackinder's or Spykman's concepts), played by the greatest powers, does not cease. However, its nature has changed because the players, instead of expanding their military armouries, prefer to take advantage of their economic potentials.

It should be noticed that economics has almost always been harnessed in war and international confrontations. The economic blockades of towns, financial penalties or import duties are tools that have been used by quarrelling parties since ancient times. Therefore, geoeconomics should not be considered anything new. However, this is not the case, because changes taking place in the world lead to the fact that geoeconomic tools are chosen much more frequently not only because of their bloodless nature, but also due to their effectiveness. Among the factors that influenced this state of affairs are:

- Dislike of traditional wars;

- Progressing globalization is the reason why world markets are much more tightly connected with each other, bigger, inclined to overreactions and reacting to new information extremely rapidly. As long as military intervention used to be considered the quickest form of influencing decisions of a given state, the contemporary financial markets allow for almost instant obtaining of the desired effect;

- The world financial crisis made national governments realize the fact that "capital has nationality" and, due to uneconomic reasons, they become a priority during an emergency;

- States dispose of bigger and bigger economic potential that can be instantly used in the event of international tensions. Analysts usually focus on the growing level of public debt, though the parallel process is the increase in assets (foreign-exchange reserves, sovereign wealth funds and state-owned enterprises) managed directly or indirectly by the governors.

Geoeconomics is therefore nothing new, though in the changing reality, it has acquired a much higher status.

The aim of this article is not to identify actions of a geoeconomic nature much better deliberations of this kind can be found somewhere else (Blackwill - Harris 2015). However, it is good to roughly indicate the types of instruments used for geoeconomic purposes together with examples of such actions: 
1) Trade policy

a. Import bans (Russia prohibits the import of wine from Georgia, chocolate from Ukraine, countries that allow for the Dalai Lama's visit experienced a decline in exports to China of around $8 \%$ );

b. Taxes and import quotas (import duties imposed by the US on imports from China);

c. Hidden trade barriers - aware of the implementation of regulations concerning health, safety or other aspects in order to exclude particular goods / enterprises from the national market.

2) Investment policy

a. State-owned companies (increasing or decreasing purchases on indicated markets);

b. Sovereign wealth funds - decisions regarding the purchase or sale of actions and bonds in world markets (in 2013, Russia offers Ukraine the rescue package. Financial resources for this purpose are going to be taken from the sovereign wealth fund);

c. Government expenditures (decisions regarding the purchase of weapons, technologies, resources from particular countries).

3) Resources policy

a. Dictating prices, threats regarding the possibility of refraining from transporting the resource, setting different prices for different countries (Gazprom policy).

4) Foreign exchange policy

a. Weakening the currency, currency wars (current conflict between the US and China).

5) Financial assistance

a. Providing conditional assistance (In 2013, Saudi Arabia provides the government in Lebanon with assistance in the amount of $\$ 3$ billion. These funds are supposed to be spent on the purchase of French weapons), supporting countries of great geopolitical significance.

6) Technological advancement

a. "Tech - war" for global leadership in technological innovation (Huawei, ZTE Corp.);

b. Cyberattacks. Stealing data of major economic or military significance (the number of breaches like that decreases globally on October $1^{\text {st }}$ each year that is on the day when people in China celebrate their national holiday).

These are only a few tools in the geoeconomic arsenal of contemporary states. Governments start to use them more frequently and effectively. 
In this context, it is also worth mentioning a few other things. Most importantly, not every country can dispose of geoeconomic instruments to the same extent. The factors enabling that are: economic potential, a relatively large internal market and the "nation's robustness". The first factor does not have to be commented on. A large internal market is important mainly because it serves as the buffer weakening the negative influence of retaliatory instruments. For instance, if country X cannot export a given good to country Y, the resulting loss from this will be definitely smaller if manufacturers of this good find consumers on the national market. On the other hand, a large internal market serves as bait - global manufacturers care more about their presence in the countries with large markets than in the countries whose markets are relatively small.

It is way harder to explain the essence of a "nation's robustness." For the purposes of this paper, I will define it here as "being ready to sacrifice for one's country." History shows that this precise factor decided whether or not a given state become an empire. In ancient Rome, readiness for dying for the motherland was something nearly obvious; the British empire owes its greatness to, among others, the bloodshed in various continents (Ferguson 2008); and American presidential candidate John Kennedy, having said this famous sentence, was on the edge of winning the elections: "ask not what your country can do for you, ask what you can do for your country." Imperial policy and, more broadly, policy conducted on the basis of geopolitical premises, becomes easier once the nation is ready for participating in the expenses generated by it. From this point of view, some countries seem better adapted to facing geoeconomic tensions than others.

This way we reach a fundamental ascertainment. Namely, the actions of a geopolitical nature are economically ineffective. This means that evaluating them from the perspective of macro- or microeconomic models has to turn out negative. The American - Chinese "trade war" is the best example of it. The vast majority of economic analysts consider the decisions taken by the US president as wrong and unprofitable. However, this kind of argument is completely mistaken once we judge it from the perspective of the logic of war. After all, from the geopolitical point of view, nobody is questioning the fact that the confrontation of two powers must generate expenses - it is not so much about the expense itself, but rather about achieving the strategic goal.

This is a very important comment, because geoeconomics introduces some kind of chaos into the world. The economization of the majority of life's aspects resulted in the fact that most decisions are being judged on the basis of economic rationality. Economists evaluating the geoeconomic actions of states make unequivocal, negative judgments. However, the problem is that economic effectiveness is of secondary importance to strategic actions. Let me provide some ex- 
amples. Does the way of managing assets of some sovereign wealth funds seem ineffective? Yes, but our judgment can change if we take into consideration the fact that they do not necessarily have to pursue the maximization of shareholders' profits. Do state-owned companies prefer purchasing good X more expensively only in country Y as a result of the decision made "above"? Yes, but if we consider another fact, i.e. that the threat of cancelling purchases in country Y may influence other decisions taken by country $\mathrm{Y}$, then suddenly the economic ineffectiveness starts to make sense. Is Russian Gazprom oriented on the maximization of profits? Of course not, because if this was the case, Russia would lose one of its primary measures of exerting pressure on the neighbouring countries.

The chaos generated by geoeconomics means that economic ineffectiveness, contemporarily treated as the main criterion of judging the rationality of a given decision, is insufficient for the evaluation of strategic decisions, especially those motivated by geopolitics. Decisions made by the player can be evaluated as irrational only if it is well known what game we are playing. The growing popularity of geoeconomics results in the fact that players are judged based on the principles of the game differently than the one that is actually being played.

\section{GEOPOLITICS OF THE NEW SILK ROAD}

Through the prism of theoretical deliberations presented herein so far, it is useful to take a closer look at the current events that constitute some kind of source of geopolitical dynamics in the world. It obviously concerns the Chinese "Belt and Road" project, often referred to as the "New Silk Road". I assume that the reader is familiarized with this plan; therefore, I will not repeat the content that is already summarized excellently elsewhere (Chołaj 2014; Kołodko 2018; Góralczyk 2018).

I do not hesitate to claim that the vision of the New Silk Road is the same for a geopolitician as the vision of a monopoly is for an entrepreneur - a dream to some and a nightmare to others (Shahriar 2019). There are two reasons for that. Firstly, China, from the geopolitical perspective, is the country whose potential (geographical, demographic and economic) predestines it to the role of a superpower. Although this country at the time of industrial revolutions was repeatedly humiliated and in the modern history it was run under the anti-development ideology, the broader historical context indicates (Morris 2010) that it is virtually destined for the role of a leader.

Secondly, the concept of Belt and Road, understood as some kind of narrative interacts with almost every known geopolitical doctrine. This means that the New 
Silk Road cannot be geopolitically neutral. Even if none of the designers of Belt and Road ever heard about Heartland or Rimland, to the rest of the world, they will look like someone who is trying to implement the project of ruling the world.

Although China did not actively participate in "concerts of powers" that resulted in dividing the world into areas of influence, it was present in the geopolitical thought. It was treated as some kind of a "sleeping dragon" whose awakening can be of utmost importance to world politics. For instance, Mackinder believed that China would eventually be able to exercise control over a significant part of Heartland. This view was inspired by the actions of the Mongol Empire that once prevailed over Heartland and became the biggest land-based power in history. China was also discussed by Spykman. In his opinion, the economic potential and very advantageous topography of China may contribute in the future to its being able to dominate over Rimland, which, at the same time, would place it in a conflicting position towards the actions of the US. Yet, another contemporary geopolitician believes that China will eventually prevail over both Heartland and Rimland.

Finally, it should also be kept in mind that, in the world of geoeconomics, the function of an army has been recently taken over by the factors of an economic nature. This means that China does not necessarily have to take aggressive military steps in order to be a part of geopolitical narration scenarios. It can be proven by, for instance, claims that contemporary China, not being able to become a military power, has become an infrastructural one and, similar to other countries that forge strategic alliances with the US for the purpose of obtaining military assistance, such alliances are and will be forged with China, owing to the possibility of improving the national infrastructure with the help of the Chinese companies. After all, both the countries that are placed lower on the ladder of economic growth and the developed ones with their ageing infrastructure need new and cheap solutions related to building airports, railways, ports or bridges more than they need American bombers.

China then falls into some kind of a geopolitical trap. This means that any activity leading to military, territorial or economic expansion is treated as an element of implementing the plan of exercising control over the world (Fallon 2015).

The economist considers the New Silk Road project as, most importantly, bigger trade, the increase of foreign investments, the chance to expand markets in the less developed countries and diversification. On the contrary, the geopolitician perceives actions taken so far under this Chinese "Marshall Plan" rather than placing debit traps, the secret buying-out of the Western companies and technology theft.

The maritime "Belt" project, especially that concerning the "polar" one (formally attached to the Belt and Road Initiative in January 2018), assumes allowing 


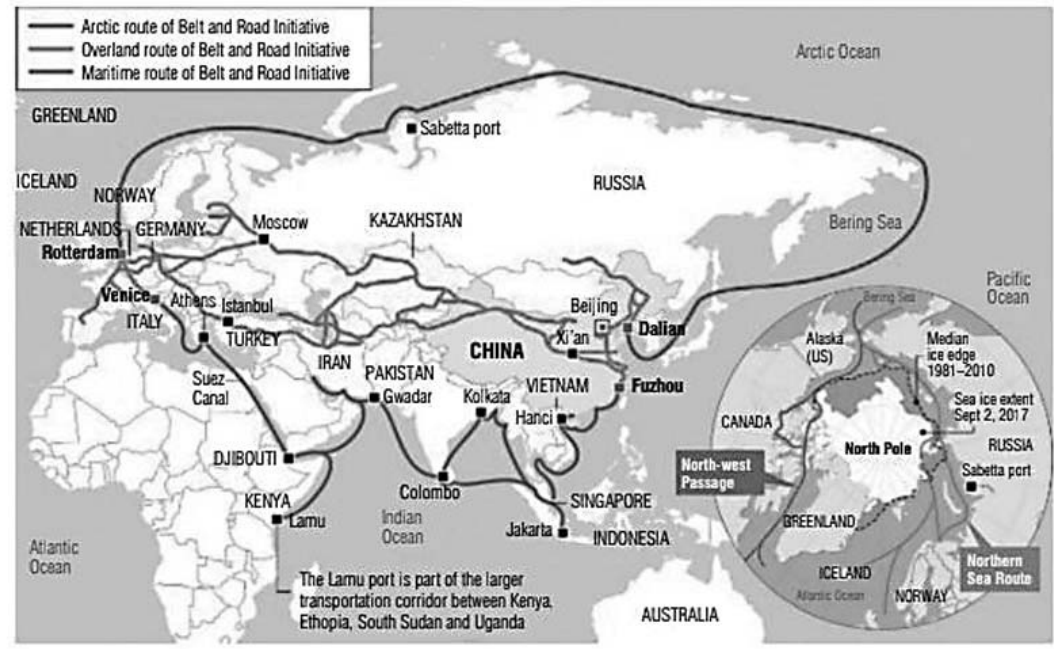

Figure 3. The Belt and Road project

Source: https://www.straitstimes.com/asia/east-asia/chinas-polar-ambitions-cause-anxiety.

for maritime shipping through the routes that were previously impossible to take by big container ships because of the thick ice cover.

The warming climate and enormous capital expenditures (among others, on icebreakers) are supposed to change this state of affairs. And, this is very important because maritime transport on this northern route would result in a significant shortening of the distance between the Atlantic Ocean and Pacific, which practically means reducing the time of maritime transport from China to Europe by as much as 12 days in comparison to the route leading through the Suez Canal.

And again... The economist considers the project of this kind as a big opportunity related to bigger competence, the diversification of transport and logistical facility (Arase 2015; Blanchard 2017). On the contrary, the geopolitician perceives this project as a kind of "Copernican revolution" (Clarke 2018). If this initiative succeeded, then the significant part (or maybe even the majority) of world trade would use the northern route. This, in turn, could mean that Russia, which throughout all recorded history has been known as the land-based power, would become a maritime power. The concepts of Heartland and Rimland could require a redefinition, and world order would have to be based on brand-new principles.

To sum up, the anxiety that geopoliticians have when they look at the Chinese plans of creating the New Silk Road should come as no surprise. However, neither should do the hopes of the economists and countries which, thanks to their geographic location, may become the beneficiaries of this project. The Chinese initiative, owing to historical analogies and the economic potential of this coun- 
try, is more of a narration rather than a detailed plan (Sen 2016). This is precisely why it arouses various extreme emotions. This is also why it is judged through the prism of different narratives (especially geopolitical) rather than on the basis of a cost-benefit analysis.

\section{GEOPOLITICS IN 16+1 FORMAT}

In 2012, a new format of China's cooperation with the countries of East-Central Europe was initiated. This new platform consisted of 16 post-communist countries, including $11 \mathrm{EU}$ members. All the countries were supposed to become the addressees of an attractive developmental offer, providing for the implementation of relatively inexpensive infrastructural projects (Gerstl 2018).

It seems though that the Chinese offer was based on the presumption that 16 countries, similar to other global beneficiaries of Chinese investments, have no access to capital (Kowalski 2017). This is visible in, for instance, the very model of the investment offer. It assumes that a given state would be granted a longterm, interest-reduced loan (provided by all Chinese banks), financing $90 \%$ of the given project value. The condition of being granted a loan is to entrust the execution to the Chinese companies and taking the Chinese subcontractors into account in the supply chain. The evaluation of this model allows for drawing the conclusion that the offer made to these 16 countries is not significantly different than cooperation proposals made to other developing countries.

In the functioning of the " $16+1$ " initiative so far, the fragmentation along the line of the European Union membership is evidently noticeable. In the nonmember countries, several projects with the value of 6 billion euro were initiated (Jakóbowski - Kaczmarski 2017), whereas in the rest of the countries (except for Hungary), no significant increase of the demand for Chinese capital can be observed.

11 countries belonging to the EU are not interested in cooperation with China because of two factors. The first one is of a legal nature. Namely, the model of cooperation provides for a no-bid determination of a contractor and public help, which is inconsistent with EU regulations. Secondly, EU members have access to alternative sources of financing within, among others, structural funds which, due to their nature (partial subsidy), are much more attractive than the Chinese offers.

Therefore, the cautious conclusion should be drawn that the success of the " $16+1$ " project requires the fundamental transformation of the cooperation model that would make the Chinese party a direct investor rather than solely a lender and contractor. Of course, this requires China's greater participation in capital and adjusting local economic and legal conditionings. 
The success of the " $16+1$ " format depends also on overcoming the difficulties of a geopolitical nature (Vangeli 2017). And, there are quite a lot of them because of the greatly increasing number of geopolitical narratives that, most frequently, lead to the finding that the Chinese project is, in its essence, the embodiment of the divide et impera principle, thus it is aimed at causing partitioning within the European Union. Making $11 \mathrm{EU}$ members (less developed than the countries of so-called "old union") dependent on Beijing will be reflected in the lack of unanimity in the EU regarding controversial Chinese initiatives and, at the same time, it will mean an increase in support for China in international organizations and the EU itself. The above thesis can be proven by the fact that it is no coincidence that Ukraine, Belarus or Moldavia are not participating in the $16+1$ project. As long as in the case of 5 participants of the $16+1$ project the EU membership is anticipated, the aforementioned 3 countries are not going to be the EU members in the predictable future.

The reasoning behind this type of narration has a geoeconomic nature and can be reduced to the lapidary phrase saying that if China gives something today, tomorrow it may decide to take it back on some pretext. The inflow of investment capital is a much desired phenomenon, although the negative consequences of a potential, politically-controlled threat of reducing such an investment flow entail the unacceptable risk.

In order to better describe the geoeconomic, negative consequences of getting involved in building the New Silk Road and the related " $16+1$ " format, I would like to propose a thought experiment.

Let us imagine that the initiator, originator and main investor of the New Silk Road is not China, but Russia. Let us assume that the essence of this project is not to build a new transportation infrastructure, but to connect Europe and Asia with a gas supply network. Let us also assume that the whole project is financed by Gazprom, Rosnieft and Russian national funds. And, finally, let us change the name of the project to the "Blue road". Does this kind of proposal arouse our hopes or rather does it cause fear? Is not the hope of cheaper gas accompanied by the automatic vision of "turning off the tap" in the case of falling under Russian disfavour? If such doubts are not taken into consideration in the case of China, it should be kept in mind that precisely China (not Russia) is considered to be the most effective geoeconomic player.

A similar thought experiment can be conducted by replacing the New Silk Road with "TP" - Transatlantic Partnership where the initiator of this project would be the US. In this case, enthusiastic slogans would meet with a very cold, even sceptical reaction of Europe, as it was the case with the wave of criticism after the conclusion of the trade agreement between the EU and Canada - "CETA". The reasons for this state of affairs can be found in the last few decades of experiencing 
the policy of the US, which, under the cover of altruistic, magnanimous slogans, forced the achievement of highly egoistic, individual goals - it offered the drugs to the world that it had never taken itself (Harvey 2005; Kołodko 2008).

From this viewpoint, China has a clean sheet, though it would be a sign of naivety to believe that China, trying to catch up the developmental delay, will become the "Santa Claus."

\section{HOW TO LIBERATE FROM GEOPOLITICAL NARRATIVES?}

Geopolitical concepts have been treated herein with a great degree of criticism, as pseudoscientific narratives that, while used by governors, become a pretext on following a particular current policy. The best solution for the world would be then to press some global "delete" key in order to erase geopolitical narratives from international discourse. However, the problem is that there is no such key, and these concepts are characterized by significant vitality and a tendency to multiply. As a result, the world becomes a slave to the so-called "minority rule" which, in this case, is reduced to a situation in which one player takes geopolitical narratives seriously, so consequently all the players must consider them, too. This way, we have to deal with the situation, which is not an optimum in a Pareto sense.

Therefore, the question that has to be asked is: what should be done in order to become free from the geopolitical ballast and contribute to the economic growth under the "Silk Road"?

The answer to this question is extraordinarily difficult and rather intuitive, starting from adopting the assumption that the New Silk Road is the project of a business nature. That is China, being in possession of surplus capital, wants to economically stimulate the less developed regions of its country and, at the same time, it wants to benefit from building infrastructure in other parts of the world.

It should be underlined that geopolitical narratives reveal attributes similar to self-fulfilling prophecies. This means that neutralization of a narration impeding economic activity has to be comparable with fighting the self-fulfilling prophecy. And the most effective way of fighting the self-fulfilling prophecy is its detailed identification (Malinowski 2012). The self-fulfilling prophecy may be defined as a situation in which false belief becomes a true one, because it causes people to behave in a certain way.

The complete identification of a self-fulfilling prophecy consists of:

1) Determining the cause-effect relationship of a given phenomenon;

2) Indicating the mistaken perception of the cause-effect relationship by at least one participant of the phenomenon;

3) Explaining where the false belief comes from; 
4) Explaining why "false belief" acquired self-fulfilling features.

Following this path, it has to be stated that China, which cares about building the New Silk Road, should:

1) Thoroughly analyse those geopolitical doctrines that may somehow concern the Belt and Road project;

2) Show internal inconsistency and contradiction of geopolitical concepts;

3) Prove that presumptions on which those concepts are based are not applicable to the Chinese project or that they are out-of-date;

4) Indicate who is the biggest beneficiary of maintaining the status quo;

5) Lead an open discussion on the subject.

The most difficult to follow is obviously the recommendation that points out the necessity of proving that geopolitical deliberations do not concern China.

However, the question automatically raised is whether China actually cares for their initiative not to be associated with clamorous projects of strictly geopolitical nature. It seems that this is the case, which can be proven by the "career" of terminology related to the Chinese project so far, which, instead of becoming more precise, moves toward blurred lines and, consequently, gradually loses its geopolitical nature (Bhoothalingam 2015). For it has to be noticed that initially the mass media had been using the phrase "New Silk Road". To historians, it is a well-known and well-defined term that almost instantly triggers associations of a geopolitical nature. However, it turned out a few years later that the Chinese project has been named a little bit differently - One Belt, One Road (OBOR). Then, here comes the term that has a slightly broader connotation, because it conveys within its scope not only the ancient land-based route, but also the sea route, which, despite being historically justified too, does not trigger such unambiguous associations. However, in the last few years, China moved from the name OBOR toward the expression Belt \& Road and, as long as the previous concepts invited only the states that were situated along the road to cooperation, the most up-todate name suggests that virtually every country is invited to cooperate with China (Hu 2018). The conclusion is then twofold - China realized that the narration concerning the Silk Road is like hitting a bull's eye in terms of marketing, but it also resembles shooting oneself in the foot when it comes to geopolitics; therefore, it is trying to make its concept as neutral as possible. Another option is that China, due to economic reasons exclusively, decided to transform its project into a campaign promoting the infrastructural offer for the whole world.

The declared growing openness of the Chinese project also has some side effects. Namely, the primary enthusiasm that the countries situated along the Silk Road engaged in this initiative is slowly diminishing. Besides, more and more 
frequent cases of taking European companies over and the lack of noticeable breakthrough progress in the implementation of the New Silk Road concept result in the fact that China's initiative is being increasingly perceived within geopolitical or marketing categories.

The history of international relations indicates two regularities. Firstly, to every action there is always a reaction, and secondly: usually it is not the strongest country that wins, but rather the country involved in the strongest alliance. Relating these observations to the Chinese issue, it has to be noticed that, within the present international configuration, only the US can be considered both as an economic and a military power. This means that China's becoming a global economic leader may cause some anxiety but, when it is accompanied by its growing military importance together with direct or indirect territorial claims, the anxiety transforms into fear. The fear, in turn, makes countries build alliances pointed at China (for every action there is a reaction) - it is worth noticing that a way of responding to the Chinese project was the Trans-Pacific Partnership (TPP), which was supposed to become a geoeconomic weapon aimed at China. Although the main initiator of this project - the US - renounced it first, it can be assumed that subsequent anti-China initiatives (such as a trade war) are only a matter of time.

Therefore, the final conclusion is that the Belt \& Road project can be implemented on the condition that China withdraws from the arms race or its appearances. Unless it happens, any initiative of an economic nature will be perceived as the one of a geoeconomic nature and, at the same time, as the element of implementing some bigger geopolitical project. Although diminishing military ambitions do not guarantee changes to the way China's actions are globally perceived, it definitely weakens the argument of those who, due to ideological reasons, block the economic growth of China and countries wanting to cooperate with it.

\section{SUMMARY}

The success of both the " $16+1$ Initiative" and the Belt \& Road project depends not only on economic or even political factors, but also on increasingly popular geopolitical narratives. However, while economic factors can be directly addressed and changed, or at least it is well known how to solve problems related to them, it is not clear how to neutralize geopolitical narratives. Furthermore, concepts arising within the framework of geopolitics have the appearance of scientific theories and geopoliticians like to speak in terms of the so called "eternal laws of geopolitics". This "scientific robe" is probably the reason why the entire discipline is considered to have a scientific character. 
In this paper, I strongly emphasized the fact, that there is no rigorous methodology behind geopolitical concepts. What's more, it has been demonstrated, that they perfectly fit into the framework of self-fulfilling prophecies, i.e. false statements (or statements with unknown logical value), which become true only because they make people to become influenced by them and change their behaviour.

Despite the self-fulfilling character of geopolitical narratives, the fact that they are being used and shared by the advisers of influential politicians: Putin, Merkel, Xi Jinping or Trump - makes them important after all, and makes a pragmatic politician take them into account.

Chinese " $16+1$ " or OBOR initiative are so ambitious that it is almost impossible to find any geopolitical narration that would not cover them. Despite the undoubted benefits associated with the implementation of these projects, it is clear nowadays that geopolitical narratives prevail, and even potential beneficiary countries are paralyzed.

Last but not least, it is worth mentioning that neutralizing geopolitical narratives seems to be a necessary condition to overcome the current deadlock. And the best way to overcome any self-fulfilling process is to clearly identify it, articulate it and demonstrate the very mechanism that gives it a self-fulfilling character.

\section{REFERENCES}

Arase, D. (2015): China's Two Silk Roads Initiative: What It Means for Southwest Asia. Southeast Asian Affairs, 1: 25-45.

Bhoothalingam, R. (2015): The Silk Road as a Global Brand. ASCI Journal of Management, 44(2): $60-68$.

Chołaj, H. (2014): Chiny a Świat Współczesny. Chiński Model Ekonomiczny (China and Contemporary World. The Chinese Economic Model). Warsawa: SGH, Warsaw School of Economics.

Clarke, M. (2018): The Belt and Road Initiative: Exploring Beijing's Motivations and Challenges for Its New Silk Road. Strategic Analysis, 42: 84-102.

Blackwill, R. D. - Harris, J. M. (2015): War by Other Means. New York: Belknap Press.

Blanchard, F. - Flint, C. (2017): The Geopolitics of China's Maritime Silk Road Initiative. Geopolitics, 22(2): 223-245.

Eberhardt, P. (2011): Halford Mackinder's Concept of Heartland. Przeglad Geograficzny, 83(2): 251-266.

Eberhardt, P. (2014): Nicholas Spykman's Concept of Rimland i jej konsekwencje geopolityczne (Nicholas Spykman's Concept of Rimland and Its Geopolitical Consequences). Przeglad Geograficzny, 86(2): 261-280.

Fallon, T. (2015): The New Silk Road: Xi Jinping's Grand Strategy for Eurasia. American Foreign Policy Interest, 37(3): 140-147.

Ferguson, N. (2008): Empire. How Briatin Made the Modern World? New York: Penguin.

Gerstl, A. (2018): China's New Silk Roads. Categorising and Grouping the World: Beijing's 16+1+X European Formula. Vienna Journal of East Asian Studies, 10(1): 31-58. 
Góralczyk, B. (2018): Wielki Renesans (A Great Renaissance). Warsawa DIALOG.

Harvey, D. (2005): A Brief History of Neoliberalism. New York: Oxford University Press.

Hu, B. (2018): The Belt and Road Initiative and the Transformation of Globalization. ALK \& TIGER Distinguished Lectures Series, No. 26, http://www.tiger.edu.p1/DL26.pdf

Jakóbowski, J. - Kaczmarski, M. (2017): Nietrafiona oferta Pekinu: "16+1" a chińska polityka wobec Unii Europejskiej (An Unsuccessful Beijing Offer: "16+1" and Chinese Policy towards the EU). Warsawa Centre for Eastern Studies, OSW (Ośrodka Studiów Wschodnich).

Kołodko, G. W. (2008): Truth, Errors and Lies. Politics and Economics in a Volatile World. New York: Columbia University Press.

Kołodko, G. W. (2018): Socialism, Capitalism, or Chinism? Communist and Post-Communist Studies, 51(4): 285-298.

Kotarbiński, T. (1955): Dzieta Wszystkie. Traktat o dobrej robocie (A Treaty about Good Work). Republished: Warsaw, Wydawnictwo Ossolineum, 2000.

Kowalski, B. (2017): China's Foreign Policy towards Central and Eastern Europe: The "16+1" Format in the South-South Cooperation Perspective. Cases of the Czech Republic and Hungary. Cambridge Journal of Euroasian Studies, 16(1): 153-162.

Luttwak, E. (1990): From Geopolitics to Geo-Economics: Logic of Conflict, Grammar of Commerce. National Interest, 20: 17-23.

Luttwak, E. (2001): Strategy. The Logic of War and Peace. Cambridge: The Belknap Press.

Mackinder, H. (1904): The Geographical Pivot of History. The Geographical Journal, 23(4): 421437.

Malinowski, G. M. (2012): Samospełniająca się przepowiednia-definicja, identyfikacja i wyzwania (Self-fulfilling Prophecy-Definition, Identification and Challenges). Transformacje, 1(72): 2-20.

Merton, R. K. (1948): The Self Fulfilling Prophecy. The Antioch Review, 8(2): 193-210.

Moczulski, L. (1999): Geopolityka. Warsaw: Bellona.

Morris, I. (2010): Why the West Rules - for Now. New York: Farrar, Straus and Giroux.

Piskozub, A. (2010): Miejsce geopolityki w klasyfikacji dyscyplin nauki z geografią, historią i polityką w ich nazwach (Positioning of Geopolitics in the Classification of Disciplines Containing Geography, History and Politics in Their Name). Przeglad Geopolityczny, 2: 29-43.

Płaczek, J. (ed.) (2015): Współczesna wojna handlowo - gospodarcza (A Contemporary Trade War). Warsaw: Difin.

Rodrik, D. (2011): The Globalization Paradox: Democracy and the Future of the World Economy. New York: Norton.

Shahriar, S. (2019): The Belt and Road Initiative: What will China Offer the World in Its Rise. Asian Journal of Political Science, 27(1): $152-156$.

Sen, G. (2016): China - One Belt and One Road Initiative: Strategic \& Economic Implications. New Delhi: VIVEKANANDA International Foundation.

Soros, G. (2008): The New Paradigm for Financial Markets: The Credit Crisis of 2008 and What It Means. New York: Public Affairs.

Schelling, T. (1960): The Strategy of Conflict. Cambridge: Harvard University Press.

Spykman, N. (1944): The Geography of the Peace. New York: Harcourt, Brace and Company.

Sułek, M. (2001): Podstawy Potegonomii I Potęgometrii (Principles of Powernomics and Powermetrics). Kielce: Kieleckie Towarzystwo Edukacji Ekonomicznej.

Sułek, M. (2008): Trzy Działy Prakseologii (Three Dimensions of Praxeology). Scientific Year's Issue of the Faculty of Management in Ciechanów of Wyższa Szkoła Menedżerska, 2(1-2): 51-70.

Vangeli, A. (2017): China's Engagement with the Sixteen Countries of Central, East and Southeast Europe under the Belt and Road Initiative. China \& World Economy, 25(5): 101-124. 